\title{
Hubungan Respon Imun Humoral dengan Derajat Trombositopenia pada Pasien Demam Berdarah Dengue
}

\author{
Fatmawati, ${ }^{1}$ Chandra Wijaya ${ }^{2}$
}

\begin{abstract}
The correlation between humoral immune response with the level of of thrombocytopenia on dengue hemorrhagic fever patient The aim of this study was to know the correlation between humoral immune response with the level of of thrombocytopenia on dengue hemorrhagic fever patient. This is a cross sectional analytical study on internal inpatients of AwalBros Pekanbaru Hospital in August-November 2008. Population was all internal inpatients of AwalBros Pekanbaru Hospital with working diagnosis dengue hemorrhagic fever. There were 4 pattern of anti Dengue antibody : IgG-/IgM, IgG-/IgM+, IgG+/IgM-, IgG+/IgM+. Most of patients with IgG+/IgM+ and have secondary dengue infection Those result were analyzed by Friedman statistical test. There isn't a significant correlation between the level of thrombocytopenia and anti dengue antibody. It show that there wasn't a direct correlation between them. It could be due to a cross reaction between anti dengue antibody with thrombocyte (autoantibody).
\end{abstract}

Keywords: dengue hemorrhagic fever, thrombocytopenia, anti dengue antibody

Demam dengue Dengue (DBD) adalah penyakit infeksi demam (febris) akut yang disebabkan oleh 4 serotipe virus dengue (DEN-1, DEN-2, DEN-3, DEN-4) dengan daya infeksi yang tinggi pada manusia. Virus dengue masuk ke dalam tubuh manusia melalui gigitan nyamuk Aedes aegypti dan Aedes albopictus. ${ }^{1}$

Virus berkembang biak dalam tubuh manusia di sel retikuloendotelial, kemudian terjadi viremia yang berlangsung selama 5-7 hari dan diikuti dengan respon imun tubuh terhadap virus dengue. Respon imun tubuh penderita demam berdarah dengue dan demam dengue terdiri dari respon imun yang tidak spesifik dan respon imun spesifik yang meliputi respon imun humoral dan seluler. ${ }^{2}$

Pada respon imun non spesifik penderita DBD, yang berperan adalah makrofag, komplemen, dan trombosit. Pada respon kekebalan humoral yang berperan adalah $\operatorname{IgG}$ dan IgM bekerjasama dengan kekebalan tubuh non spesifik membentuk antibody

1 Penulis untuk korespondensi : Bagian Patologi Klinik Fakultas Kedokteran Universitas Riau, Jl. Diponegoro no 1 Pekanbaru Telp. (0761) 839264.

2 Bagian Fisiologi Fakultas Kedokteran Universitas Riau dependent cytotoxic cell (ADCC). Sedangkan pada respon kekebalan seluler yang berperan adalah sel limfosit T Sitotoksik, CD-8, MHC Klas I, IL-1, IL6 , TNF alfa, dan interferon (IFN). ${ }^{3}$

Respon imun humoral yang timbul akibat infeksi virus ini memunculkan antibodi. Antibodi yang muncul pada umumnya adalah IgG dan IgM. Pada infeksi dengue primer antibodi baru mulai terbentuk, sedangkan pada infeksi sekunder kadar antibodi yang telah ada menjadi meningkat (booster efect). Antibodi terhadap virus dengue dapat ditemukan di dalam darah sekitar demam hari ke 5, meningkat pada minggu pertama sampai dengan ketiga, dan menghilang setelah 60-90 hari. $^{4}$

Kinetik kadar IgG berbeda dengan kinetik kadar IgM, sehingga kinetik antibodi IgG harus dibedakan antara infeksi primer dan sekunder. Pada infeksi primer antibodi IgG meningkat sekitar demam hari ke-14 sedang pada infeksi sekunder antibodi IgG meningkat pada hari kedua. Oleh karena itu diagnosa dini infeksi primer hanya dapat ditegakkan dengan mendeteksi antibodi IgM setelah hari sakit kelima dan diagnosis infeksi sekunder dapat ditegakkan lebih dini dengan adanya peningkatan antibodi IgG dan IgM yang cepat. ${ }^{5}$ 
Pada respon imun yang tidak spesifik setelah terinfeksi virus dengue maka akan terjadi aktivasi sistem komplemen C, depresi sumsurn tulang yaitu tahap hipovaskuler pada hari ke 3-4 demam dan perubahan patologis sistem megakariosit. Respon trombosit terhadap aktivitas tersebut secara urnum ada 4 tipe yaitu perubahan bentuk trombosit dari keping pipih menjadi bulat berduri, adhesi, agregasi dan sekresi. Selama stadium demam hitung trombosit mulai menurun dan mencapai nilai terendah selama stadium renjatan, kemudian meningkat dengan cepat pada stadium konvalesen. Biasanya kembali normal dalam 7-10 hari. Hitung trombosit <100.000/ul (trombositopeni) terdapat pada hari ke 3-8 demam dan paling sering pada hari ke enam. ${ }^{6}$

Dalam praktek sehari-hari diagnosis DBD ditegakkan berdasarkan gejala klinis dan pemeriksaan laboratorium. Pemeriksaan laboratorium yang sering diminta adalah pemeriksaan hematologi sederhana meliputi kadar hemoglobin, hematokrit, jumlah leukosit dan hitung trombosit serta pemeriksaan antibodi IgG dan IgM dengue. Pada kenyataannya sering didapatkan ketidaksesuaian antara hasil hitung jumlah trombosit dengan hasil pemeriksaan antibodi. Sebagai contoh pada satu kasus penderita demam dengan gejala klinis DBD dan jumlah trombosit sangat menurun (severe trombositopenia), ternyata pada pemeriksaan antibodi didapatkan hasil negatif. Pada penderita lain dengan klinis DBD dan hitung trombosit normal atau sedikit menurun malahan didapatkan hasil pemeriksaan antibodi (IgG dan atau IgM) positif. Ketidaksesuaian tersebut seringkali menimbulkan pertanyaan tentang bagaimana hubungan kedua pemeriksaan laboratorium tersebut.

Sebagai usaha untuk mencari jawaban atas masalah tersebut maka penulis tertarik untuk mengadakan penelitian dengan tujuan mencari hubungan antara respon imun humoral dengan derajat trombositopenia pada pasien DBD.

\section{METODE}

Penelitian ini merupakan penelitian analitik dengan studi potong lintang (cross sectional). Penelitian dilakukan di bagian rawat inap penyakit dalam RS Awal Bros (RSAB) Pekanbaru dari bulan
Agustus-November 2008. Populasi penelitian adalah seluruh penderita yang dirawat di bagian penyakit dalam RSAB dengan diagnosis kerja demam berdarah dengue. Sampel diambil secara consecutive sampling dengan jumlah sample $(\mathrm{n})=$ 30. Untuk pemeriksaan jumlah trombosit berupa darah vena yang dikumpulkan dalam tabung EDTA $2 \mathrm{ml}$. Bahan untuk pemeriksaan antibody IgG dan IgM Dengue berupa serum yang diambil bersamaan dengan pengambilan darah EDTA. Pengambilan darah dilakukan pada demam hari ke-5 atau lebih.

Sebelum dilakukan pengambilan sample darah terlebih dahulu dicatat data pasien yang meliputi umur, jenis kalamin, lama demam, nomor rekam medis. Selanjutnya dilakukan pengambilan darah vena untuk pemeriksaan jumlah trombosit dan pemeriksaan IgG dan IgM Dengue. Pemeriksaan trombosit dilakukan pada alat hematologi otomatik Sysmex XT 1800 memakai darah dengan antikoagulan EDTA. Hasil yang didapat dicetak dan dilaporkan sebagai jumlah trombosit per mikro liter darah. Berdasarkan jumlah trombosit, maka penderita dikatakan mengalami trombositopenia bila didapatkan hasil trombosit $<150.000 /$ ul. Derajat trombositopenia selanjutnya diklasifikasikan menjadi ringan, sedang dan berat dengan kriteria seperti terdapat dalam Tabel 1:

Tabel 1. Klasifikasi derajat trombositopenia

\begin{tabular}{ll}
\hline Derajat tro mbositopenia & Jumbh trombosit (ul) \\
\hline Ringan & $>100-150.000 / \mathrm{ul}$ \\
Sedang & $>50.000-100.000 / \mathrm{ul}$ \\
Berat & $10.000-50.000 / \mathrm{ul}$
\end{tabular}

Pemeriksaan antibodi IgG dan IgM Dengue dilakukan dengan reagen Panbio Dengue Duo IgM dan IgG rapid Strip Tes. Hasil yang didapat dicatat dan dilaporkan sebagai negatif atau positif dengan interpretasi seperti tabel 2:

Tabel 2. Interpretasi pemeriksaan antibodi Dengue

\begin{tabular}{lll}
\hline IgG & IgM & Interp retasi \\
\hline- & - & negatif \\
- & + & positif dengue primer \\
+ & - & positif dengue se kunder \\
+ & + & positif dengue se kurder
\end{tabular}


Data yang terkumpul dimasukkan ke dalam tabel induk lalu diolah dengan uji statistic yang sesuai secara komputerisasi dengan program SPSS versi 15.0

\section{HASIL}

Pada penelitian yang dilakukan terhadap penderita dengan klinis DBD yang dirawat di Bagian Penyakit Dalam RS. Awal Bros Pekanbaru dari bulan September sampai Oktober 2008 didapatkan sampel sebanyak 30 orang. Pada gambar 1 dapat dilihat distribusi penderita DBD menurut jenis kelamin. Hampir tidak terdapat perbedaan jumlah antara penderita pria yaitu sebanyak 15 orang $(50 \%)$ dan wanita sebanyak 15 orang (50\%) dengan ratio 1:1.

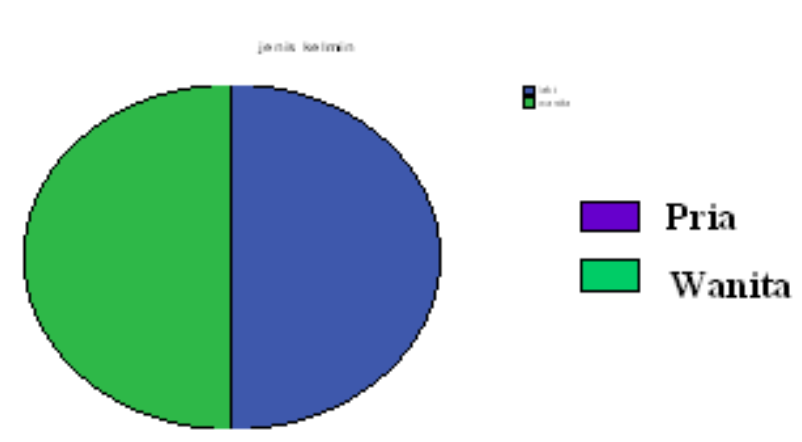

Gambar 1. Distribusi penderita DBD menurut jenis kelamin
Rerata umur penderita adalah 28 tahun \pm 10 tahun, dengan umur termuda 16 tahun dan tertua 56 tahun.

\section{Gambaran penderita DBD menurut beratnya manifestasi klinis pada saat dirawat}

Beratnya manifestasi klinis pada saat dirawat dinilai dari lama demam pada saat masuk rumah sakit (Tabel 3), derajat manifestasi klinis pada saat masuk rumah sakit (Tabel 4) dan gambaran laboratorium hematologi penderita DBD pada saat masuk RS (Tabel 5).

Tabel 3. Lama demam pada saat masuk rumah sakit

\begin{tabular}{ccc} 
Lama demam & Jumlah (n) & Persentase $(\%)$ \\
\hline hari ke -2 & 2 & 6,7 \\
hari ke -3 & 13 & 43,3 \\
hari ke -4 & 10 & 33,3 \\
hari ke -5 & 5 & 16,7 \\
hari ke -6 & 0 & 0
\end{tabular}

Tabel 4. Derajat manifestasi klinis DBD pada saat masuk rumah sakit

\begin{tabular}{lcc}
\multicolumn{1}{c}{ Stadium DBD } & Jumlah(n) & Persentase $(\%)$ \\
\hline Derajat I & 5 & 16,7 \\
Derajat II & 23 & 76,7 \\
Derajat III & 2 & 6,6 \\
Derajat IV & 0 & 0
\end{tabular}

Tabel 5. Gambaran laboratorium hematologi penderita DBD pada saat masuk RS

\begin{tabular}{lccc}
\hline \multicolumn{1}{c}{ Variabel } & Jumlah $(\mathrm{n})$ & Rata-rata simpang baku & Kisaran \\
Hemoglobin & 30 & $14,06 \pm 1,72$ & $11,20-18,20$ \\
Hematokrit & 30 & $41,85 \pm 5,69$ & $32,70-54,90$ \\
Leukosit & 30 & $4125 \pm 2450$ & $1500-12.200$ \\
Trombosit & 30 & $79.166 \pm 33.143$ & $26.000-149.000$ \\
\hline
\end{tabular}

\section{Gejala klinis penderita DBD dengan konfirmasi serologis}

Berdasarkan pada beberapa gejala klinis yang timbul pada penderita DBD, didapatkan gejala demam pada semua kasus dikuti oleh muntah dan nyeri perut. Gambaran gejala klinis secara lengkap dapat dilihat pada Tabel 6. 
Tabel 6. Gejala klinis DBD dengan konfirmasi serologis

\begin{tabular}{lcc}
\hline & Gejalaklinis & Jumlah kasus (\%) \\
Demam & 100 \\
Muntah & 78 \\
Nyeri perut & 52 \\
Melena & 4 \\
Epistaksis & 3 \\
Batuk & 23 \\
Diare & 5 \\
Hepatomegali & 45 \\
\hline
\end{tabular}

\section{Gambaran jenis infeksi penderita DBD}

Dalam penelitian ini terdapat 30 sampel darah yang terkumpul dari 30 orang yang didiagnosis klinis DBD. Dari total 30 sampel tersebut dilakukan pemeriksaan anti dengue $\operatorname{IgG}$ dan IgM sehingga dapat ditentukan jenis infeksi yang diderita. Pada umumnya infeksi yang terjadi merupakan infeksi sekunder (tabel 7 dan gambar 2).

Tabel 7. Karakteristik infeksi penderita DBD

\begin{tabular}{|c|c|c|}
\hline Infeksi & Jumlah kasus (n) & Persentase (\%) \\
\hline Negatif & 8 & 26,7 \\
\hline Primer & 5 & 16,7 \\
\hline Sekunder & 17 & 56,6 \\
\hline Total & 30 & 100,00 \\
\hline
\end{tabular}

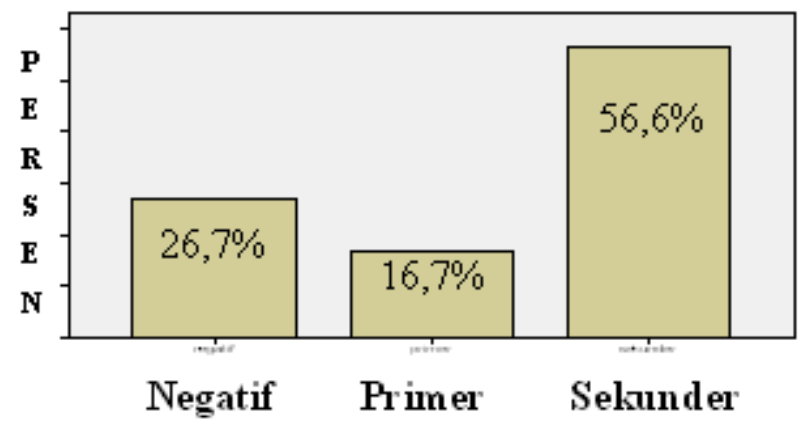

Gambar 2. Karakteristik infeksi penderita DBD

\section{Hubungan antara respon imun humoral dengan derajat trombositopenia}

Berdasarkan jumlah trombosit penderita dikelompokkan atas trombositopenia ringan, trombositopenia sedang dan trombositopenia berat. Berdasarkan pemeriksaan anti Dengue respon imun penderita dikelompokkan atas $\operatorname{IgG}(-) / \operatorname{IgM}(-$ ), $\operatorname{IgG}(+) / \operatorname{IgM}(+), \operatorname{IgG}(+) / \operatorname{IgM}(-)$ dan $\operatorname{IgG}(-) / \operatorname{IgM}$ $(+)$. Pada umumnya penderita termasuk kelompok trombositopenia sedang dan respon imun yang muncul kebanyakan berupa $\operatorname{IgG}(+) / \operatorname{IgM}(+)$, namun 8 penderita yang mengalami trombositopenia, pada pemeriksaan antibodi didapatkan hasil IgG (-) / $/ g M$ (-). Setelah dilakukan uji Friedman untuk mencari apakah terdapat hubungan antara respon imun humoral dengan derajat trombositopenia didapatkan p > 0,05 seperti terlihat pada Tabel 8 . 
Tabel 8. Hubungan antara respon imun humoral dengan derajat trombositopenia

\begin{tabular}{lcccc}
\hline Respon Imun & Ringan & $\begin{array}{c}\text { Trombositopeni } \\
\text { Sedang }\end{array}$ & Berat & Jumlah \\
& 4 & 4 & 0 & \\
\hline IgG (-)/IgM (-) & 2 & 8 & 3 & 8 \\
IgG(+)/IgM (+) & 0 & 3 & 1 & 13 \\
IgG (+)/IgM (-) & 1 & 3 & 1 & 5 \\
IgG (-)/IgM (+) & 7 & 18 & 5 & 30 \\
Jumlah & \multicolumn{5}{c}{$\mathrm{p}=0,12$} \\
\hline Uji Friedman & \multicolumn{5}{l}{} \\
\hline
\end{tabular}

\section{PEMBAHASAN}

Dari 30 orang penderita yang dirawat dengan klinis DBD, sebagian besar merupakan dewasa muda, rerata umur 28 tahun \pm 10 tahun. Penemuan ini dapat dijelaskan karena kelompok usia ini memilki mobilitas yang tinggi untuk datang ke tempat-tempat umum seperti sekolah, mesjid dan pasar sehingga kemungkinan mereka terifeksi virus dengue melalui gigitan nyamuk lebih tinggi.

Tidak terdapat perbedaan jenis kelamin antara pria dan wanita menunjukkan bahwa tidak ada perbedaan gender dalam infeksi oleh virus ini. Laporan yang sama juga diberikan oleh Sugianto dkk yang mendapatkan $51 \%$ wanita dan $49 \%$ pria dengan rasio wanita dan pria 1,04:1,0.

Pada penelitian ini juga diperoleh hasil bahwa sebagian besar penderita dirawat di rumah sakit pada hari ke-3 demam, dan sebagian besar didiagnosis sebagai DBD derajat $2(76,7 \%)$. Tidak ada penderita yang didiagnosis dengan DSS pada saat pertamakali dirawat. Hal inimenunjukan rendahnya prevalensi kejadian syok pada infeksi virus Dengue yang dirawat di Bagian Penyakit Dalam RSAB. Hal tersebut mungkin mencerminkan cukup berhasilnya usaha yang dilakukan pemerintah dan tenaga kesehatan dalam penyuluhan/kampanye kesehatan kepada masyarakat dalam mengantisipasi DBD sehingga mereka datang sesegera mungkin ke pusat pelayanan kesehatan untuk mendeteksi dan merawat gejala DBD yang dialaminya.

Berdasarkan pemeriksaan terhadap antibodi IgG dan IgM didapatkan bahwa sebagian besar penderita tergolong mengalami infeksi sekunder, hanya $16,7 \%$ yang merupakan infeksi primer. Hasil ini tidak jauh berbeda dengan hasil penelitian sebelumnya seperti Hamid F dkk yang mendapatkan persentase negatif $(31,94 \%)$, primer $(19,44 \%)$ dan sekunder $(48,62 \%)$. Hal ini dapat diterangkan karena subjek penelitian ini adalah orang dewasa yang biasanya telah mengalami infeksi dengue primer sebelumnya. Infeksi primer biasanya didapatkan pada bayi atau anak yang terinfeksi virus Dengue untuk pertama kalinya.

Tingginya angka infeksi negatif pada penelitian ini $(26,7 \%)$ kemungkinan disebabkan oleh beberapa faktor antara lain karena kemampuan deteksi kit reagen (sensitifitas reagen Panbio 99\%), kemungkinan pasien tidak menderita infeksi Dengue, melainkan oleh agen lain seperti oleh virus Japanesse encephalitis, malaria, leptospira, virus Chikungunya dan sebagainya.

Pentingnya menentukan jenis infeksi ini dalam pengelolaan penderita karena terdapat korelasi antara infeksi dengue primer-sekunder dengan beratnya penyakit, dimana manifestasi klinis infeksi dengue sekunder lebih berat dibandingkan infeksi primer(Chanthavanich P, 2006). Dari hasil observasi infeksi virus dengue di Kuba menunjukkan bahwa kasus DBD/DSS lebih banyak terjadi pada infeksi sekunder.

Seperti terlihat pada Tabel 8 , umumnya penderita mengalami trombositopenia sedang dan pola antibodi yang muncul adalah IgG positif dan IgM positif. Hasil uji Friedman untuk mencari hubungan antara respon imun humoral dengan derajat trombositopenia tidak didapatkan korelasi yang bermakna $(\mathrm{p} 0,12)$ antara terbentuknya antibodi IgG dan atau IgM dengan severitas trombositopenia sehingga pada pasien DBD dengan trombositopenia berat dapat diperoleh hasil uji $\operatorname{IgG}$ dan atau $\operatorname{IgM}$ negatif, sedangkan pada penderita trombositopenia ringan bisa didapatkan IgG dan atau IgM negatif. 
Hal ini dapat diterangkan kemungkinan karena tidak terdapat hubungan langsung antara $\mathrm{IgG}$ dan IgM dengan trombositopenia. Terjadinya trombositopenia pada DBD disebabkan oleh multifaktor antara lain (1) Penurunan produksi trombosit oleh megakariosit akibat depresi sumsum tulang (2) Peningkatan bersihan trombosit yang terikat oleh antibodi spesifik (immune-mediated clearance). Peningkatan konsumsi trombosit oleh karena terjadinya aktifasi koagulasi/agregasi trombosit melalui aktifasi trombosit dan komplemen serta terjadinya peningkatan destruksi trombosit melalui sitolisis dan apoptosis melalui mekanisme autoimun. Munculnya fenomena autoimunitas pada DBD ini sampai sekarang belum dapat dijelaskan bagaimana imunopatogenesis pastinya. Sampai sekarang belum banyak penelitian yang memfokuskan kepada masalah ketidaksesuaian antara jumlah derajat trombositopenia dengan munculnya antibody terhadap dengue, namun terdapat beberapa teori yang dikemukakan oleh beberapa peneliti yang mencoba menjelaskan mekanisme terjadinya trombositopenia pada penderita DBD ditinjau dari aspek autoimunitas yang diperantarai oleh antibodi anti trombosit.

Beberapa teori yang dikemukan adalah teori mimikri molekular (molecular mimicry) antara antigen Dengue dengan antigen host (self antigen). Teori ini menerangkan bahwa akibat infeksi virus Dengue maka host akan membentuk antibodi terhadap antigen virus seperti terhadap antigen NS1 dan antigen prM. Antibodi ini selanjutnya akan bereaksi silang (cross-reaction) dengan trombosit dan sel endotel. ${ }^{7}$ Ikatan antara antibodi dan antigen (trombosit atau sel endotel) ini menyebabkan terjadinya aktifasi komplemen dan menimbulkan lisis trombosit (complement-mediated lysis) atau memacu sinyal intraseluler yang menimbulkan produksi Nitric Oxide dan apoptosis. ${ }^{7}$

\section{KESIMPULAN}

Tidak didapatkan hubungan langsung antara respon imun humoral (IgG dan IgM) dengan derajat trombositopenia. Antibodi yang mungkin lebih berpengaruh terhadap derajat trombositopenia pada penderita DBD adalah autoantibodi anti trombosit.

\section{UCAPAN TERIMA KASIH}

Kami mengucapkan terima kasih kepada Direktur RSAB Pekanbaru yang telah memberikan izin untuk melaksanakan penelitian ini di RSAB Pekanbaru. Terima kasih juga kami ucapkan kepada lembaga penelitian Universitas Riau yang telah memberikan kesempatan dan bantuan dana sehingga penelitian ini dapat terlaksana dengan baik.

\section{DAFTAR PUSTAKA}

1. Suroso, Chrishantoro T. Informasi produk PanBio Dengue Duo IgM dan IgG Rapid Strip Test.PT. Pacific Biotekindo Intralab. $3^{\text {-rd }} \mathrm{Ed}$ Jakarta;2004

2. Novriani H. Respon imun dan derajat kesakitan Demam Berdarah Dengue dan Dengue Syok Sindrom. Cermin Dunia Kedokteran 2002; 134:p.46-8

3. Hamid F., Sjahril R., Massi M.N. Imunoglobulin G dan M pada Penderita Suspek Demam Berdarah Dengue. J Med Nus 2006; 27 (3) : p.164-6

4. Kresno S.B. Imunologi :Diagnosis dan prosedur laboratorium. Balai Penerbit FKUI. Jakarta; 1999:p. 78-8

5. Harikushartono, Hidayah N, Darmowandowo W, Soegijanto S. Demam Berdarah Dengue: Ilmu Penyakit Anak, Diagnosa dan Penatalaksanaan. Salemba Medika. Jakarta;2002

6. Howarth MC, Miyajima A, Coffman R. Cytokine: Paul Fundamental Immunology. $3^{\text {rd }}$ Ed. 1994: p.763-90

7. Yao Lei-Huan. The Role of anti-Dengue antibodies in the pathogenesis of Dengue disease. The FASEB J 2008;22: p. 861-8 